\title{
Analisis Media, Sumber Belajar, dan Bahan Ajar Yang Digunakan Guru Fisika SMA Materi Gelombang Di Sumatera Barat Ditinjau Dari Kebutuhan Belajar Abad 21
}

\author{
Putri Bullquis Marsa ${ }^{1}$, Desnita ${ }^{2)}$ \\ ${ }^{1)}$ Magister Pendidikan Fisika, Universitas Negeri Padang \\ 2) Universitas Negeri Padang \\ putribullquismarsa.a2@gmail.com ${ }^{1)}$ \\ desywaznadil@gmail.com ${ }^{2}$
}

\begin{abstract}
This study aims to look at the media, learning resources, and teaching materials used by physics teachers of high school for wave material. In accordance with the learning needs of 21st century, the media used must be IT-based. To see how important the use of IT media in learning process is conducted research with descriptive analysis research type. The data of this study were obtained with interview guidelines, directly with teachers distributing questionnaires the availability of media, learning resources, and teaching materials in schools to respondents, namely teachers in seven schools, and distributing questionnaires for learning resources and teaching materials consisting on identity and indicators of aspects reviewed in learning resources and teaching materials. Based on results of data acquisition, it was found that teacher has not used much media in the learning process. In fact, for 21st century learning, IT-based learning media are needed so students can practice 4C skills (critical thinking, creativity, communication, and collaboration).
\end{abstract}

Keywords : Learning Media, Learning Resources, Teaching Materials, Wave, 21st Century Learning Needs This is an open access article distributed under the Creative Commons 4.0 Attribution License, which permits unrestricted use, distribution, and reproduction in any medium, provided the original work is properly cited. $\odot 2020$ by author and Universitas Negeri Padang.

\section{PENDAHULUAN}

Manusia dan pendidikan merupakan satu kesatuan yang tidak dipisahkan. Pendidikan merupakan satu dari banyaknya unsur terpenting dalam hidup berbangsa dan bernegara (Saputra, $\mathrm{dkk}, 2019)$. Untuk membangun suatu peradaban manusia pada setiap negara diperlukan pendidikan. Pendidikan merupakan upaya sadar dan terencana dalam mewujudkan suasana dan proses pembelajaran yang mana siswa dapat mengembangkan potensi diri sehingga setiap siswa mempunyai jiwa spiritual yang tinggi, kepribadian yang baik, mampu mengendalikan diri dalam berbagai kondisi, berakhlak mulia, memiliki kecerdasan, dapat mengembangkan keterampilan dan segala potensi yang dimiliki siswa (Depdiknas, 2003).

Pada hakikatnya, pendidikan adalah suatu upaya mempersiapkan siswa untuk menghadapi kehidupan yang senantiasa selalu berubah setiap waktu (Apriyanti, dkk, 2015). Melalui pendidikan, seluruh potensi siswa dapat dikembangkan baik melalui pengembangan bakat dan minat, maupun melalui rekayasa kondisi lingkungan pembelajaran yang kondusif. Semua hal yang menyangkut pendidikan selalu mengalami perubahan atau bersifat dinamis, artinya pendidikan akan selalu bergerak dan berkembang sesuai dengan perkembangan zaman. Pendidikan berperan sebagai jembatan yang menghubungkan individu manusia dengan lingkungannya, sehingga individu dapat menjadi manusia yang berkualitas, di tengah era globalisasi yang terus berkembang dan maju. Manusia yang berkualitas adalah manusia yang dapat mengetahui dan memahami pengetahuan, serta dapat mengaplikasikannya dalam kehidupan sehari-hari sehingga dapat bermanfaat untuk dirinya dan masyarakat di sekitarnya (Al-Idrus, 2015). Menurut Marcelina, dkk (2018), dengan adanya manusia yang berkualitas dalam kehidupan, berbagai ilmu pengetahuan dan teknologi dapat dikendalikan, dikuasai, dan dimanfaatkan, termasuk ilmu fisika.

Menurut Asrizal, dkk (2018), fisika merupakan salah satu suatu ilmu pengetahuan yang menarik dikarenakan fisika mampu menjelaskan bagaimana proses dari kerja-kerja yang ada di dunia. Fisika lahir dan berkembang dari keingintahuan yang besar. Rasa ingin tahu ini mendorong dan memotivasi manusia untuk selalu bertanya dan mencoba menjawab pertanyaan mereka tentang apa, mengapa, dan bagaimana mengenai fenomena alam yang 
terjadi disekitarnya. Zulherman, dkk (2014) menyatakan fisika adalah suatu pengetahuan yang menarik. Hal ini dikarenakan dalam ilmu fisika selalu mengkaji fenomena, peristiwa, dan kejadian alam yang nampak di lingkungan sekitar. Sedangkan menurut Wartono (2003), fisika merupakan suatu bangun ilmu pengetahuan yang mana menjelaskan dan menggambarkan usaha, wawasan, temuan, dan kearifan manusia yang bersifat kolektif. Objek kajian fisika adalah alam yang mana merupakan kumpulan dari benda-benda dan peristiwaperistiwa yang saling berhubungan antar satu dengan lainnya (Mundilarto, 2010). Senada dengan itu, Ahmadi dan Supriyono (2003) menyatakan fisika tidak hanya sekedar berbagai kumpulan fakta dan prinsip, tetapi juga mengandung cara dan sikap fisikawan dalam memperoleh fakta dan prinsip tersebut. Dalam menemukan produk-produk fisika, diperlukan langkah-langkah saintis, yaitu melakukan observasi, melakukan pengukuran, merumuskan dan menguji hipotesis, mengumpulkan data, melakukan eksperimen, dan prediksi terhadap hasil eksperimen yang diperoleh. Dalam konteks ini, fisika tidak hanya sekedar cara melihat, berpikir, dan bekerja saja, akan tetapi juga sebagai proses yang meliputi sikap/tindakan, keingintahuan yang besar, cara berpikir terhadap objek yang diamati, dan seperangkat prosedur yang harus dilakukan dalam menemukan jawaban terhadap apa yang diamati. Jadi, pembelajaran fisika meliputi apa yang dipelajari siswa, bagaimana siswa belajar dan proses yang dialami.

Dalam prosesnya, pembelajaran hendaknya dapat memotivasi, memberikan aspirasi dan tantangan, serta mendorong kreativitas siswa (Asrizal, dkk, 2018). Begitu pula dengan pembelajaran fisika. Pembelajaran fisika membahas tentang fenomena-fenomena dialam semesta yang diperkuat oleh fakta-fakta yang berisikan konteks-konteks pelajaran dimana perlu analisis untuk memecahkan suatu masalah yang terkandung di dalamnya. Pembelajaran fisika sebaiknya juga bersifat konkrit yaitu mampu memberikan daya tarik bagi siswa, memberikan percepatan pemahaman, menghilangkan kebosanan, menyajikan pesan yang jelas, untuk dapat meningkatkan prestasi dan pengetahuan siswa.

Banyak upaya yang dilakukan pemerintah agar pembelajaran fisika di sekolah dapat berjalan dengan baik, diantaranya adalah pembenahan kurikulum, mulai dari kurikulum 1994, sampai sekarang ini yaitu Kurikulum 2013, yang mana menjadikan pembelajaran berpusat pada siswa bukan pada guru lagi. Kurikulum 2013 mengikuti dan menyesuaikan dengan perubahan ilmu pengetahuan dan teknologi, filosofis, psikologi, dan sosiologis (Festiyed, 2015). Selain itu, pemerintah juga melakukan peningkatan kualitas tenaga pengajar agar tercipta tenaga pendidik yang profesional. Dan juga pengadaan sarana dan prasarana pendidikan agar siswa dapat dengan mudah belajar secara aktif. Dengan adanya usaha ini, seharusnya pembelajaran fisika menjadi lebih baik.

Namun kenyataan yang ada di lapangan memperlihatkan bahwa kualitas pembelajaran fisika yang mana termasuk bagian dari pembelajaran sains tergolong cukup memprihatinkan. Hal ini dapat dilihat dari hasil Program for Internasional Student Assesment (PISA) tahun 2018 yang dirilis oleh Organisation for Economic Co-operation and Development (OECD), bahwa Indonesia berada diperingkat ke-72 dari 77 negara, dengan rincian rata-rata skor sains 396, sedangkan rata-rata skor OECD 489. Dalam pembelajaran sains, untuk menguji kemampuan berpikir kritis dapat dilakukan tes pilihan ganda dan tes keterampilan (Ennis, 1993; Ennis, 1996), serta tes uraian (Ennis, 1993). Dengan diperolehnya hasil skor rata-rata sains Indonesia yang masih tergolong rendah sebagaimana yang dirilis oleh PISA, menunjukkan bahwa tingkat kemampuan berpikir kritis siswa masih tergolong rendah.

Permasalahan pembelajaran fisika lainnya adalah masih banyak guru yang menggunakan sumber belajar dan bahan ajar pada materi gelombang kurang bervariasi. Sumber belajar merupakan sesuatu yang mengandung pesan atau digunakan untuk menyampaikan pesan yang akan diberikan kepada siswa dalam proses pembelajaran (Hafid, 2011). Direktorat Pembinaan SMA (2010) menjelaskan bahwa sumber belajar merupakan semua lingkungan sekitar siswa, benda dan orang yang memiliki pesan dan informasi, yang digunakan siswa untuk melakukan proses perubahan sikap dan transfer ilmu. Sumber belajar mencakup orang, benda, lingkungan, atau wujud tertentu lainnya yang dapat digunakan siswa dalam kegiatan pembelajaran, dimana dapat digunakan secara terpisah ataupun terkombinasi, sehingga memudahkan tercapainya tujuan pembelajaran 
siswa. Komponen sumber belajar meliputi pesan, matri (media-software), peralatan (hardware), teknik, manusia, dan metode yang digunakan secara terpisah maupun dikombinasikan, hal ini dilakukan untuk memfasilitasi terjadinya tindak dan kegiatan belajar siswa (Mulyadi dan Primasari, 2014). Terdapat beberapa keuntungan menggunakan sumber belajar dalam proses pembelajaran yaitu sebagai berikut: (1) Dapat mengeksplorasi bakat terpendam siswa yang selama ini tidak tampak, (2) Materi pembelajaran menjadi mudah dipahami oleh siswa, dan (3) Siswa dapat belajar teratur dan sesuai dengan kecepatan dan waktu yang tersedia (Abdullah, 2012).

Sedangkan bahan ajar merupakan semua bentuk bahan yang berupa seperangkat materi yang disusun sistematis untuk memudahkan siswa serta membantu guru dalam menjalankan proses pembelajaran (Direktorat Pembinaan SMA, 2010). Depdiknas (2006) menyatakan bahan ajar adalah segala bentuk bahan yang digunakan untuk membantu guru melaksanakan kegiatan pembelajaran. Bahan ajar tersebut terdiri atas bahan tertulis dan tidak tertulis. Bahan tertulis seperti modul, lembar kerja siswa, handout, buku, brosur, wallchart, leaflet, sedangkan bahan tidak tertulis seperti VCD, kaset, radio, CD interaktif, video/film, dan internet. Bahan ajar menjadi salah satu faktor penting efektifnya sebuah proses pembelajaran (Arsanti, 2018). Menurut Depdiknas (2004), bahan ajar yang baik memiliki karakteristik sebagai berikut yaitu 1) Isi/substansi materi diakumulasi dari Kompetensi Dasar, 2) Mudah dipahami dan dibaca, dan 3) Memiliki daya tarik bagi guru maupun siswa. Selain kurangnya variasi, sumber belajar dan bahan ajar yang digunakan di sekolah juga masih ada yang belum memenuhi tuntutan kurikulum 2013.

Selain itu, penggunaan media pembelajaran materi gelombang dalam kegiatan pembelajaran juga masih rendah. Hal ini berarti penggunaan media belum sesuai dengan kebutuhan.

Terlepas dari sumber belajar dan bahan ajar yang digunakan harus memenuhi tuntutan kurikulum 2013, tentunya dalam proses pembelajaran juga harus memenuhi kebutuhan belajar pada abad 21 yaitu keterampilan $4 \mathrm{C}$ (critical thinking, creativity, communication, dan collaboration) dan melek IT. Untuk menunjang pemenuhan kebutuhan belajar tersebut diperlukan media pembelajaran.
Pembelajaran abad 21 ditandai dengan adanya perubahan, perkembangan, dan kemajuan teknologi informasi dan komunikasi yang pesat. Kemajuan sains dan teknologi dalam bidang cognitive science, bio-molecular, information technology dan nano-science, merupakan kelompok ilmu pengetahuan yang menjadi ciri dari abad ke-21 (Wijaya, dkk, 2016). Perkembangan dan kemajuan ini menuntut perubahan cara belajar siswa dan cara mengajar guru dalam dunia pendidikan (Yulianisa, dkk, 2018). Perubahan terbesar yang harus dijalani adalah dengan memberikan media pembelajaran, sumber belajar, dan bahan ajar yang berbasis IT dalam kegiatan pembelajaran. Manusia pada abad ke-21 harus mampu berpikir kritis, kreatif, bekerja keras, bekerja sama dalam kelompok, menciptakan penyelesaian untuk permasalahan yang sulit, menemukan prinsip dan penemuan baru, dan menciptakan cara baru dalam menyampaikan gagasan baru (Putri, 2018). Manusia abad ke-21 juga dituntut untuk menjadi pembelajar mandiri (Zubaidah, 2018). Selain memiliki keterampilan $4 \mathrm{C}$, siswa harus mampu menggunakan media pembelajaran berbasis IT.

Media pembelajaran memegang peran yang penting dalam kegiatan/aktivitas belajar (Suriyani, 2016). Media pembelajaran merupakan alat yang digunakan untuk mengefektifkan komunikasi dan interaksi guru dan siswa dalam kegiatan pembelajaran (Usmeldi, 2017). Media dikelompokkan menjadi tiga kelompok yaitu 1) Media audio, penggunaannya menekankan pada unsur audio/pendengaran, contohnya radio dan piringan hitam, 2) Media visual, penggunaannya menekankan pada unsur visual/penglihatan, contohnya gambar, diagram, dan grafik, dan 3) Media audio visual, mempunyai unsur suara dan gambar, contohnya video, film, dan televisi (Djamarah dan Zain, 1997). Media pembelajaran menjadi faktor pendukung dalam tercapainya tujuan pembelajaran (Yunita dan Wijayanti, 2017). Selain itu, media pembelajaran juga merupakan bagian integral dari kagiatan/aktivitas pembelajaran (Leonda, dkk, 2015). Dengan menggunakan media pembelajaran dapat memperjelas penyajian pesan dan informasi sehingga mempermudah, memperlancar, dan meningkatkan proses pembelajaran (Arsyad, 2011).

Melalui penelitian ini, peneliti ingin mengungkapkan media, sumber belajar, dan 
bahan ajar materi gelombang yang digunakan menurut data di lapangan.

\section{METODE PENELITIAN}

Jenis penelitian adalah penelitian deskriptif analisis, yang memberikan gambaran terhadap objek yang akan diteliti melalui data atau sampel yang terkumpul sebagaimana adanya, tanpa melakukan analisis dan membuat kesimpulan yang berlaku untuk umum (Sugiyono, 2009).

Populasi merupakan subjek atau objek yang ditentukan oleh peneliti dan mempunyai kualitas serta karakteristik tertentu untuk dan disimpulkan dan dipelajari (Sugiyono, 2017). Objek penelitian adalah media, sumber belajar, dan bahan ajar yang digunakan di tujuh sekolah di Sumatera Barat yaitu SMAN 1 Sungai Geringging, SMAN 1 Nan Sabaris, SMAN 2 Pasaman, SMAN 16 Padang, SMAN 7 Sinjunjung, SMAN 1 Sawahlunto, dan SMAN 2 Bukittinggi.

Teknik pengumpulan data dilakukan dengan melakukan wawancara menggunakan lembar pedoman wawancara penggunaan media pembelajaran di sekolah langsung dengan guru di sekolah, menyebarkan angket ketersediaan media pembelajaran, sumber belajar, dan bahan ajar yang ada di sekolah kepada responden yaitu guru di tujuh sekolah, dan menyebarkan angket sumber belajar dan bahan ajar yang ada di sekolah yang mana terdiri atas identitas dan indikator dari aspek yang yang ditinjau pada sumber belajar dan bahan ajar.

Analisis data dari angket menggunakan dua tipe penilaian, yaitu a) Menggunakan skala Likert. Skala Likert yang digunakan adalah (1) Jarang, (2) Kadang-kadang, (3) Sering, dan (4) Selalu, dan b) pemberian skor ada dan tidak. Skor bernilai (1) jika yang ditanya ada dan (0) jika yang ditanya tidak ada.

Untuk mengetahui nilai yang diperoleh siswa dengan cara membagi skor yang diperoleh dengan skor total, kemudian dikalikan dengan 100. Secara sistematis nilai setiap indikator ditentukan dari persamaan :

$$
\text { Nilai }=\frac{\text { skor } \text { yang diperoleh }}{\text { skor } \text { total }} \times 100
$$

\section{HASIL DAN PEMBAHASAN}

Hasil penelitian studi pendahuluan meliputi lembar pedoman wawancara langsung dengan guru, angket mengenai angket ketersediaan media pembelajaran, sumber belajar, dan bahan ajar di sekolah, serta angket mengenai sumber belajar dan bahan ajar di sekolah.

Berdasarkan studi pendahuluan yang telah dilakukan pada tujuh sekolah di Sumatera Barat diperoleh bahwa sumber belajar dan bahan ajar materi gelombang yang digunakan dalam proses pembelajaran fisika yaitu buku teks, buku pengayaan, buku referensi, LKS, modul, kamus, dan ensiklopedi. Sumber belajar dan bahan ajar yang digunakan dalam kegiatan pembelajaran pada setiap sekolah ditunjukkan pada Tabel 1 .

Tabel 1. Sumber Belajar dan Bahan Ajar di Sekolah

\begin{tabular}{cc}
\hline Nama Sekolah & $\begin{array}{c}\text { Sumber Belajar } \\
\text { dan Bahan Ajar }\end{array}$ \\
\hline SMAN 1 Sungai & Buku teks dan LKS \\
Geringging & Buku teks \\
SMAN 1 Nan Sabaris & Buku teks \\
SMAN 2 Pasaman & Buku teks \\
SMAN 16 Padang & Buku teks dan LKS \\
SMAN 7 Sinjunjung & Buku teks, modul, \\
SMAN 1 Sawahlunto & LKS dan ensikoledi \\
& Buku teks dan LKS \\
\hline
\end{tabular}

Berdasarkan Tabel 1, dari delapan guru di tujuh sekolah yang dilakukan observasi diperoleh bahwa $100 \%$ guru menggunakan buku teks dalam kegiatan/aktivitas pembelajaran. Buku teks yang digunakan oleh delapan guru dari tujuh sekolah tersebut sebanyak empat macam. Persentase penggunaan buku teks di sekolah disajikan pada Gambar 1.

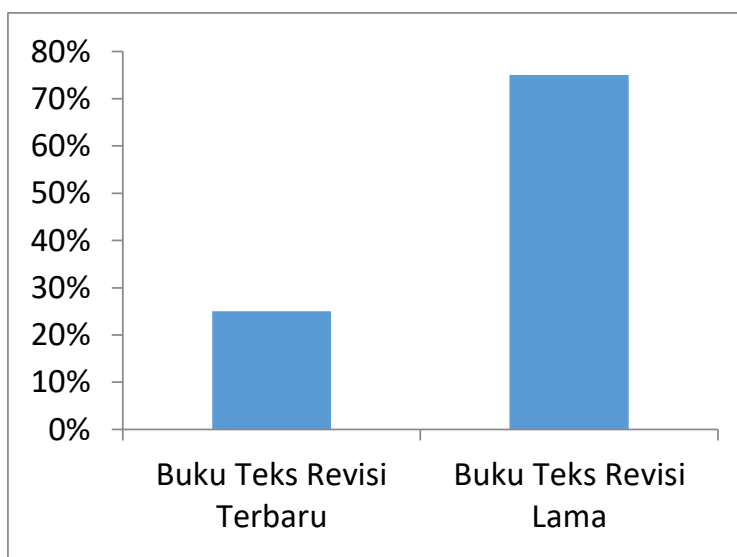

Gambar 1.Persentase Penggunaan Buku teks di Sekolah

Berdasarkan Gambar 1, dari empat buku teks yang digunakan oleh guru, hanya $25 \%$ guru yang menggunakan buku teks revisi terbaru kurikulum 2013. Buku teks revisi terbaru 
kurikulum 2013 sudah sesuai kurikulum 2013 yang menekankan perubahan paradigma: (1) Siswa yang diberi tahu menjadi siswa mencari tahu, artinya pembelajaran berpusat pada siswa, (2) Guru yang merupakan satu-satunya sumber belajar menjadi pembelajaran yang menggunakan berbagai sumber belajar, dan (3) pendekatan tekstual yang berfokus pada teori saja menjadi pendekatan proses yang lebih menekankan pentingnya aktivitas belajar siswa selama belajar, sebagai penguatan penggunaan pendekatan ilmiah. Sedangkan $75 \%$ guru menggunakan buku teks revisi lama. Jadi tidak semua guru menggunakan buku teks revisi terbaru dikarenakan buku tersebut didistribusian di sekolah.

Selain $100 \%$ guru menggunakan buku teks, 12,5\% guru menggunakan modul. Ditinjau dari segi isi materi, cara penyajian, kebahasaan, dan kegrafisan modul maka diperoleh modul belum sesuai dengan tuntutan kurikulum 2013. 62,5\% guru menggunakan LKS. LKS yang digunakan juga belum sesuai tuntutan kurikulum 2013 yang dapat melatih keterampilan berpikir kritis dan kreatif siswa, dan $12,5 \%$ guru menggunakan ensiklopedia, sedangkan bahan ajar lainnya yaitu buku pengayaan, buku referensi, dan kamus hampir tidak digunakan dalam kegiatan/aktivitas pembelajaran. Persentase penggunaan sumber belajar dan bahan ajar di sekolah dapat dilihat pada Gambar 2.

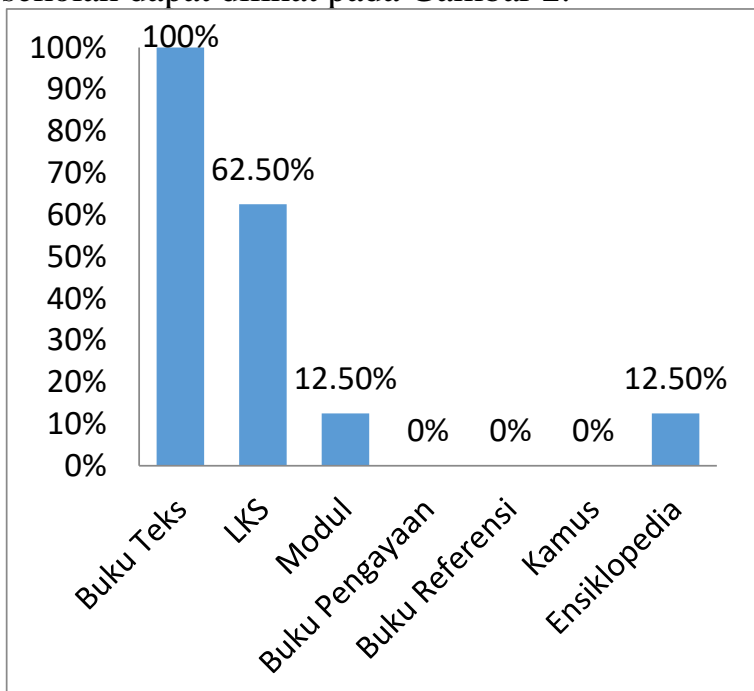

Gambar 2. Persentase Penggunaan Sumber Belajar dan Bahan Ajar di Sekolah

Gambar 2 menjelaskan bahwa penggunaan sumber belajar dan bahan ajar sangat mempengaruhi ketercapaian tujuan pembelajaran terutama materi gelombang. Dan juga membuktikan bahwa masih rendahnya penggunakan sumber belajar dan bahan ajar yang sesuai dengan tuntutan pembelajaran abad 21, yaitu melek IT.

Selain itu, hasil angket mengenai ketersediaan media pembelajaran materi gelombang yang digunakan oleh delapan guru pada tujuh SMA di Sumatera Barat dengan pilihan yaitu gambar, bagan, grafik, power point, radio, video, dan CAI, sebagaimana disajikan pada Tabel 2.

Tabel 2. Media Pembelajaran di Sekolah

\begin{tabular}{cc}
\hline Nama Sekolah & Media Pembelajaran \\
\hline SMAN 1 Sungai & Tidak menggunakan \\
Geringging & media apapun \\
SMAN 1 Nan & Tidak menggunakan \\
Sabaris & media apapun \\
SMAN 2 Pasaman & Tidak menggunakan \\
& media apapun \\
SMAN 16 Padang & Power point \\
SMAN 7 & Power point \\
Sinjunjung & \\
SMAN 1 & Tidak menggunakan \\
Sawahlunto & media apapun \\
SMAN 2 & Power point \\
Bukittinggi & \\
\hline
\end{tabular}

Berdasarkan Tabel 2 diperoleh bahwa tiga dari delapan guru menggunakan media power point dalam proses pembelajaran, padahal media power point tidak sepenuhnya dapat melatih keterampilan $4 \mathrm{C}$ dan pembelajaran juga hanya berlangsung satu arah, belum tuntutan kurikulum 2013, serta tidak akan memperbaiki keterampilan menggunakan IT bagi siswa. Sedangkan lima orang guru lainnya tidak menggunakan media pembelajaran selain papan tulis, disebabkan 1) Kurangnya sarana dan prasarana di sekolah dalam mendukung penggunaan media pembelajaran, 2) Kurangnya keterampilan guru dalam menyajikan materi pembelajaran menggunakan media pembelajaran khususnya berbasis IT, dan 3) Kurangnya persiapan guru dalam menyiapkan media dalam pembelajaran. Hal ini menunjukkan bahwa penggunaan media pembelajaran masih rendah. Meskipun pembelajaran pada abad 21 menggunakan media pembelajaran berbasis IT tetapi kenyataannya guru masih banyak menggunakan media pembelajaran non-IT.

Dari hasil wawancara dengan guru di sekolah bahwa tidak sampainya $50 \%$ guru menggunakan media pembelajaran materi gelombang dalam kegiatan pembelajaran 
disebabkan oleh berbagai faktor, seperti ditunjukkan pada Tabel 3.

Tabel 3. Permasalahan Yang Dihadapi Dalam Penggunaan Media Pembelajaran

\begin{tabular}{|c|c|}
\hline Nama Sekolah & $\begin{array}{c}\text { Permasalahan Yang } \\
\text { Dihadapi Dalam } \\
\text { Penggunaan Media } \\
\text { Pembelajaran } \\
\end{array}$ \\
\hline $\begin{array}{l}\text { SMAN } 1 \text { Sungai } \\
\text { Geringging }\end{array}$ & $\begin{array}{l}\text { Keterbatasan waktu } \\
\text { untuk membuat dan } \\
\text { kurang tersedianya } \\
\text { infokus }\end{array}$ \\
\hline $\begin{array}{c}\text { SMAN } 1 \text { Nan } \\
\text { Sabaris }\end{array}$ & $\begin{array}{l}\text { Keterbatasan waktu } \\
\text { untuk membuat dan } \\
\text { kurang tersedianya } \\
\text { infokus }\end{array}$ \\
\hline SMAN 2 Pasaman & $\begin{array}{l}\text { Kurangnya waktu un- } \\
\text { tuk mempersiapkan } \\
\text { media dan infokus } \\
\text { jumlahnya terbatas } \\
\text { sehingga sering } \\
\text { kegiatan pembelajaran } \\
\text { tidak lagi sesuai } \\
\text { dengan yang di- } \\
\text { rencanakan }\end{array}$ \\
\hline SMAN 16 Padang & $\begin{array}{c}\text { Kurangnya waktu un- } \\
\text { tuk mempersiapkan } \\
\text { media lain }\end{array}$ \\
\hline $\begin{array}{c}\text { SMAN } 7 \\
\text { Sinjunjung }\end{array}$ & $\begin{array}{c}\text { Kurangnya waktu un- } \\
\text { tuk mempersiapkan } \\
\text { media lain }\end{array}$ \\
\hline $\begin{array}{c}\text { SMAN } 1 \\
\text { Sawahlunto }\end{array}$ & $\begin{array}{c}\text { Keterbatasan waktu } \\
\text { untuk membuat dan } \\
\text { kurang tersedianya } \\
\text { infokus }\end{array}$ \\
\hline $\begin{array}{l}\text { SMAN } 2 \\
\text { Bukittinggi }\end{array}$ & $\begin{array}{c}\text { Kurangnya waktu un- } \\
\text { tuk mempersiapkan } \\
\text { media lain }\end{array}$ \\
\hline
\end{tabular}

Berdasarkan hasil wawancara pada delapan guru di tujuh sekolah bahwa rendahnya penggunaan media dalam proses pembelajaran disebabkan karena masih rendahnya kemampuan guru dalam mengoperasikan media dalam proses pembelajaran didalam kelas, tidak cukupnya waktu yang didapat guru dalam membuat media pembelajaran khusunya berbasis IT yang sesuai dengan materi yang akan diajarkan dikarenakan banyaknya beban guru selain tugas mengajar yang dibebankan kepadanya, dan tidak lengkapnya sarana dan prasarana yang menunjang dalam pengoperasionalan media pembelajaran di kelas.
Untuk mengatasi permasalahan yang dihadapi guru dalam menggunakan media saat proses pembelajaran diperlukan peran berbagai pihak terutama pemerintah, yaitu sebagai berikut : 1) Diperlukan pelatihan secara berkala bagi guru untuk melatih kemampuan pedagogik guru dalam mengoperasionalkan media pembelajaran. Mustahil siswa akan mahir dalam menggunakan media saat belajar jika gurunya juga tidak mampu. Dengan adanya pelatihan ini diharapkan guru bisa menggunakan media dalam proses pembelajaran sehingga media, sumber belajar, dan bahan ajar menjadi bervariasi. Belajar tidak hanya menggunakan buku teks saja tapi juga divariasikan dengan media pembelajaran terbasis IT seperti tuntutan pembelajaran pada abad 21 ini, 2) Meminimalisir beban guru di sekolah. Sekarang ini, tugas guru tidak hanya mengajar dan membimbing siswa di kelas, tetapi beban teknis dan struktural juga besar, seperti mengurus dokumen-dokumen yang dibutuhkan pihak sekolah. Hal ini mengganggu fokus guru dalam mengajar sehingga guru kekurangan waktu menyiapkan media pembelajaran, dan 3) Pengadaan sarana dan prasarana. Pengadaan sarana infokus yang kurang menjadi kendala besar bagi penyajian media pembelajaran. Bagaimana bisa guru dapat menyampaikan materi melalui media jika infokusnya masih belum lengkap. Jika ketiga langkah tersebut dilakukan maka menjadi solusi yang tepat sehingga permasalahan yang dihadapi guru dalam proses pembelajaran dapat teratasi.

Di era pembelajaran abad 21 ini, penting sekali bahwa pembelajaran dikelas hendaknya dapat melatih keterampilan 4C (critical thinking, creativity, communication, and collaboration) siswa dan tentunya berbasis IT. Penerapan keterampilan 4C sangat besar pengaruh dan manfaatnya bagi siswa dalam kehidupannya sehari-hari, sehingga siswa dapat hidup bersaing dengan yang lain dengan baik dengan rasa kepercayaan diri yang tinggi, di dunia yang berbasis digital pada abad 21 ini. Keterampilan 4C dalam kehidupan menjadi hal yang sangat penting karena siswa dapat berkembang dengan mudah di dunia kerja nantinya. Dengan mengkombinasikan pengetahuan dan keterampilan, serta didukung oleh standar-standar dan penilaian, kurikulum dan instruksi, adanya pengembangan secara profesional, dan lingkungan belajar yang memadai, maka siswa lebih terlibat dalam proses pembelajaran dan 
siap berkembang dan bersaing di dunia yang saling terhubung secara digital. Dengan demikian, siswa akan menjadi pribadi yang sukses dan maju dalam berbagai aspek kehidupan yang dijalaninya.

\section{KESIMPULAN}

Berdasarkan analisis dari hasil wawancara langsung dengan guru mengenai penggunaan media pembelajaran materi gelombang di sekolah menunjukkan bahwa masih banyak guru yang belum menggunakan media pembelajaran terutama yang berbasis IT dalam kegiatan pembelajaran dikarenakan kurang persiapan dalam menyiapkannya, kurangnya kemampuan guru dalam menggunakan media saat belajar, dan banyaknya beban guru diluar tugas mengajar.

Selain itu, hasil angket angket ketersediaan media, sumber belajar, dan bahan ajar materi gelombang yang ada di sekolah menunjukkan bahwa $100 \%$ guru menggunakan buku teks, $62,5 \%$ guru menggunakan LKS, $12,5 \%$ guru menggunakan modul, dan $12,5 \%$ guru menggunakan ensiklopedia. Sedangkan untuk media pembelajaran yang digunakan hanya $37,5 \%$ guru menggunakan power point dan $62,5 \%$ guru tidak menggunakan media apapun selain papan tulis.

Sementara itu berdasarkan hasil angket sumber belajar dan bahan ajar yang ada di sekolah yang mana terdiri atas identitas dan indikator dari aspek yang ditinjau pada sumber belajar dan bahan ajar menunjukkan bahwa dari empat buku teks yang digunakan oleh delapan guru hanya $25 \%$ guru menggunakan buku teks revisi terbaru dan $75 \%$ guru menggunakan buku teks lama, dan untuk guru yang menggunakan LKS dan modul, masih belum sesuai tuntutan kurikulum 2013. Jadi pada umumnya masih banyak guru yang belum menggunakan media, sumber belajar, dan bahan ajar yang sesuai dengan tuntutan pembelajaran abad 21. Padahal pada pembelajaran abad 21 sekarang ini media pembelajaran, sumber belajar, dan bahan ajar berbasis IT terutama sangat dibutuhkan dalam proses pembelajaran sehingga dapat melatih keterampilan 4C siswa, sehingga siswa menjadi pribadi yang cerdas, kritis, keatif, dan pekerja keras, yang tidak kalah bersaing dengan kompetitor lainnya. Keterampilan $4 \mathrm{C}$ ini sangat membantu siswa dalam dunia kerja nantinya sehingga dapat menjadi manusia yang kompetitif.

\section{DAFTAR PUSTAKA}

Abdullah, Ramli. (2012). Pembelajaran berbasis pemanfaatan sumber belajar. Jurnal Ilmiah DIDAKTIKA. Februari 2012. Vol. XII No. 2, 216-231.

Ahmadi dan Supriyono. (2003). Teori Belajar dan Pembelajaran. Bandung : Remaja Rosdakarya.

Al-Idrus, Syayid Qosimm. Jafar, Hikmawati, dan Wahyudi. (2015). Pengaruh Model Pembelajaran Berbasis Masalah Berbantuan Video Kartun Terhadap Hasil Belajar Fisika Siswa Kelas XI SMAN 1 Sikur Tahun Ajaran 2014/2015. J. Pijar MIPA, Vol. X No.1.

Apriyanti, Rika,. Desnita, dan Esmar. (2015). Pengembangan Modul Berbasis Contextual Teaching And Learning (CTL) Dilengkapi Dengan Media Audio-Visual Untuk Meningkatkan Hasil Belajar Fisika Peserta Didik SMA. Prosiding Seminar Nasional Fisika (E-Journal) SNF2015.

Arsanti, Meilan. (2018). Pengembangan Bahan Ajar Mata Kuliah Penulisan Kreatif Bermuatan Nilai-Nilai Pendidikan Karakter Religius Bagi Mahasiswa Prodi PBSI, FKIP, UNISSULA. Jurnal Kredo. Vol. 1 No. 2. ISSN 2599-316X.

Arsyad, Azhar. (2011). Media Pembelajaran. Jakarta : PT. Raja Grafindo Persada.

Asrizal, Arnel, Hidayati, dan Festiyed. (2018). Penerapan Model Pembelajaran Penemuan Mengintegrasikan Laboratorium Virtual dan Hots untuk Meningkatkan Hasil Pembelajaran Siswa SMA Kelas XI. Prosiding Seminar Nasional Hibah Program Penugasan Dosen ke Sekolah (PDS)Universitas Negeri Padang.

Asrizal, Yohandri, dan Zulhendri Kamus. (2018). Studi Hasil Pelatihan Analisis Video dan Tool Pemodelan Tracker pada Guru MGMP Fisika Kabupaten Agam. JEP | Volume 2 | Nomor 1| Mei 2018 e-ISSN 2579-860X p-ISSN 2614-1221 Doi: https://doi.org/10.24036/jep/vol2-iss1/84.

Departemen Pendidikan Nasional. (2003). Sistem Pendidikan Nasional. Jakarta : Direktorat Jenderal Pendidikan.

Depdiknas. (2004). Materi Pelatihan Terintegrasi Bahasa Indonesia. Jakarta : Dirjen Dikdasmen. 
Departemen Pendidikan Nasional. (2006). Pedoman Memilih dan Menyusun Bahan Ajar. Jakarta: Depdiknas.

Djamarah, Syaiful Bahri, dan A. Zain. (1997). Studi Kasus (Desain dan Metode). Jakarta : PT Raja Grafindo.

Direktorat Pembinaan SMA. (2010). Juknis Pengembangan Bahan Ajar SMA. Jakarta : Departemen Pendidikan Nasional.

Ennis, R. H. (1993). Critical thinking assessment. Theory Into Practice, 32(3), pp. 179186.

Ennis, R. H. (1996). Critical thinking dispositions : their nature and assessability. Informal Logic, 18(2\&3), pp. 165-182.

Festiyed. (2015). Studi Pendahuluan Implementasi Kurikulum 2013 Dalam Mengintegrasikan Pendekatan Saintifik Melalui Model Inkuiri Dan Authentic Assesment Dalam Pembelajaran IPA di Kota Padang. Semirata.

Hafid, Abd. (2011). Sumber dan Media Pembelajaran. Sulesana.Volume 6 Nomor 2.

Leonda, M. Ardian,. Desnita, dan Agus. (2015). Pengembangan Modul Berbasis Problem Based Learning Untuk Materi Suhu dan Energi di SMA (Sesuai Kurikulum 2013). Prosiding Seminar Nasional Fisika (EJournal) SNF2015.

Marcelina, Rezi., Masril, dan Yenni Darvina. (2018). Pengembangan Media Pembelajaran Dalam Bentuk Video Tutorial Bilingual Untuk Pembelajaran Fisika Siswa SMA Kelas XI Semester1. Pillar Of Physics Education, Vol. 2.

Mulyadi, S.K. dan Primasari, F. (2014). Implementasi Perpustakaan Sekolah Sebagai Sumber Belajar Dalam Meningkatkan Prestasi Belajar Siswa. Profesi Pendidikan Dasar, Vol. 1, No. 1, Juli 2014: 1730.

Mundilarto. (2010). Penilaian Hasil Belajar Fisika. Yogyakarta : P2IS UNY.

Program For Internasional Student Assesment (PISA) Tahun 2018 Tentang Literacy Reading Science and Mathematics.

Putri, I. Ichwani. (2018). Penguasaan Keterampilan Abad 21 Peserta Didik Melalui Elemen Literasi Era Digital. Seminar Nasional Pendidikan Biologi FKIP UIR-2018.
Saputra, Novrizal., Desnita, Murtiani, dan Wahyuni. (2019). Analisis Sajian Buku Teks Pelajaran Fisika SMA Kelas XI Semester 2 Terkait Komponen Contextual Teaching And Learning (CTL). Pillar of Physics Education, Vol 12. No 3, 2019, 505-512.

Sugiyono. (2009). Metode Penelitian Kuantitatif, Kualitatif dan $R \& D$. Bandung : Alfabeta

Sugiyono. (2017). Metode Penelitian (Kuantitatif, Kualitatif, dan $R \& D$ ). Bandung : Alfabeta.

Suriyani, Indah. (2016). Pengembangan Video Pembelajaran Menggunakan Model Problem Solving Berbantu Wondershare Pada Materi Statistika di SMP. Jurnal Semarang, Universitas PGRI.

Usmeldi. (2017). Efektivitas Penerapan Media Pembelajaran Interaktif Dengan Software Autorun Untuk Meningkatkan Kompetensi Fisika Siswa SMK Negeri 1 Padang. JEP. Volume 1 | Nomor 1| Mei 2017 eISSN 2579-860X.

Wartono. (2003). Strategi Belajar Mengajar Fisika. Malang: JICA.

Wijaya, E. Yuni,. Dwi, dan Amat. (2016). Transformasi Pendidikan Abad 21 Sebagai Tuntutan Pengembangan Sumber Daya Manusia Di Era Global. Volume 1 Tahun 2016 - ISSN 2528-259X.

Yulianisa, dkk. (2018). Tinjauan Keterampilan Abad 21 (21st Century Skills) dikalangan Guru Kejuruan (Studi Kasus : SMK Negeri 2 Solok). CIVED JURUSAN TEKNIK SIPIL, Vol. XX No. X, September 2018. ISSN 2302-334.

Yunita, Dwi, dan Astuti Wijayanti. (2017). Pengaruh Media Video Pembelajaran Terhadap Hasil Belajar IPA Ditinjau Dari Keaktifan Siswa. Jurnal LP3M Universitas Sarjanawiyata Taman Siswa Yogyakarta, Vol.3, No.2.

Zubaidah, Siti. (2018). Keterampilan Abad Ke21 : Keterampilan Yang Diajarkan Melalui Pembelajaran. Seminar Nasional Pendidikan di Program Studi Pendidikan Biologi STKIP Persada Khatulistiwa Sintang-Kalimantan Barat.

Zulherman, Desnita, dan Erfan H. (2014). Studi Tentang Kebutuhan Bahan Ajar Fisika SMA Sebagai Penunjang Kurikulum 2013. Prosiding Seminar Nasional Fisika. 